\title{
O Pensamento Jurídico-Filosófico do Professor Goffredo Telles Junior*
}

\author{
Aloysio Ferraz Pereira \\ Professor Livre Docente de Filosofia \\ do Direito da Faculdade de Direito da
Universidade de São Paulo.
}

Recordemos que a terceira parte da Criação do Direito traz o subtítulo: "Esboço de uma teoria natural do direito" Este último segmento da obra é redigido em caracteres tipográficos de dimensão maior que os usados nas duas anteriores, como a indicar que o autor lhe atribui importância superior, certamente por seu cunho de originalidade e por constituir, se inão propriamente a conclusão ou conseqüência de premissas e análises expendidas nas partes precedentes, pelo menos, e com certeza, o seu esforço de superamento das posições e doutrinas examinadas. A extensão desta etapa final é, contudo, muito mais curta que a das precedentes.

Mais uma vez se faz presente, desde logo, sua constante preocupação de seguir o método e o modelo das ciências naturais. Começa, pois, por afirmar sua disposição de "afastar todos os preconceitos" ", para, ao mesmo tempo, estabelecer como ponto de partida de sua démarche final a postulação do princípio da liberdade, tal qual foi obtido demonstrativamente pelo autor na parte inicial. À afirmação de que o homem é um ser livre, diz ele, "cheguei após demonstrar que o sentimento de liberdade, de que se acha dotado o homem, longe de ser o resultado de nossa ignorância sobre a causa dos movimentos que realizamos (como quisera SpINozA), longe também de ser o efeito de uma ilusão (como admitira DUGUIT), reflete uma realidade, que a ciência moderna revelou experimentalmente" 2

* Continuação do trabalho, com o mesmo título, publicado no v. 74, 1979, desta Revista.

1. CD, p. 523 .

2. CD, p. 525 . 
Pretende o professor Goffredo TeLles JR. que a ciência experimental teria comprovado a verdade de duas substâncias: a matéria e o espírito. "A realidade total compreende, portanto, o mundo da matéria, que chamarei físico e o mundo do espírito, que chamarei psíquico." ${ }^{3}$ Parece, contudo, que o espírito veio a ser, nessa análise, apenas o irredutível resíduo da investigação a que a ciência experimental submete a matéria em seus "laboratórios" 4 .

$\mathrm{E}$ o autor articula, afinal, os dois conceitos de matéria e de liberdade, para definir negativamente a condição essencial do homem, de modo que o espírito ou o psíquico resta apenas excluído, inapreensível experimentalmente, uma sobra além da percepção apetrechada dos cientistas: "Ser livre significa ser independente das leis da matéria." 5 Portanto, fica faltando determinar positivamente a natureza desse espirito, onde 0 autor faz residir a "fonte da liberdade". ${ }^{6}$ Faltou perceber e descrever os fatos espirituais ou de consciência em uma fenomenologia do espírito, qualquer coisa parecida com o que HEGEL acreditou ter realizado. Ou então teria faltado fazer a experiência do ser espiritual, algo assim como EDITH STEIN descobriu em São João da Cruz. ${ }^{7}$ Que experiência se pode ter do espírito que não seja mística? Como também místico se pode dizer o conhecimento que deriva dessa experiência inefável. (Místico não quer dizer irreal nem é pejorativo.)

Seja como for, na perspectiva do nosso professor, os homens, enquanto entes espirituais, escolhem livremente fins, e estes, enquanto movem os homens, na realização de necessidades e possibilidades, chamam-se bens, em função dos quais eles escolhem e dispõem os seus meios.

$\mathrm{O}$ autor firma nesse ponto de seus escritos uma idéia em que de futuro sempre insistirá: "Não se confunda valor com bem. Valor é a importância atribuída por um homem a um bem, dentro da escala de seus bens." 8 Nestas reflexões axiológicas, saliente-se a seguinte asserção: "O homem descobre a ordem física, mas cria a ordem ética." ${ }^{9}$ Dela procede, como

3. CD, p. 529 .

4. CD, p. 527 .

5. CD, p. 530 .

6. CD, p. 531 .

7. CD, p. Edith Stein, La science de la croix, tr., ed. Nauwelaerts, Louvain, Paris, 1957, t. I das Oeuvres, pp. 170-208; e a obra fundamental da autora sobre o assunto: Endliches u. ewiges Sein, Herder, Friburgo/Br., 1962.

8. CD, p. 354 .

9. CD, p. 537 . 
conseqüência, a admissão das noções conexas e distintas de ser e dever-ser.

Seguindo DeL Vecchio, que na espécie glosa Fichte ${ }^{10}$, o professor GoFFrEDo TELLES JR. vai logo formular juízos, que se encadeiam num raciocinar de tipo idealista subjetivo, girando sobre um conceito do eu pensante, convertido em critério do ser. Conclui pois surpreendentemente: "o eu é o fundamento, o critério, o elemento de referência, para a medida de todos os valores. Daí a soberana dignidade do homem, cujo reconhecimento é o princípio supremo das ordens éticas." 11

Com efeito, um leitor apressado da Criação do direito não pode senão experimentar surpresa e até perplexidade diante dessa irrupção de idealismo subjetivo, sobretudo se lhe ocorre ler a passagem em questão isolada do contexto deste e dos demais escritos do autor. 0 trecho é, de fato, decisivo à determinação do que se pode - a meu ver - designar como o traço característico que individualiza toda a produção filosófica (e derivadamente jurisfilosófica) do sr. GOFFREDo TELLES JR. Este traço tem o significado de essencial contradição. Mas uma contradição, quando essencial, se explica e se justifica por si mesma. Uma tal contradição, pois, se resolve existencialmente. Quer dizer, rolando, ao mesmo tempo, sobre o ser individual do autor e sobre o seu englobante ser social, a contradição encontra superamento e síntese nessa base ôntica que, sendo biforme, é entretanto a mesma...

Noutros termos, a contradição do autor é apenas caso individual de uma das tantas contradições do seu meio social. E estas têm raízes no modo de ser de nossa existência nacional brasileira, de que o sincretismo é expressão freqüente.

A apontada contradição consiste pois em amalgamar a tendência à concepção objetiva da ciência experimental com uma concepção subjetivista e idealista, que procura apoio em DEL VECCHIO e, principalmente, em certo neokantismo rarefeito que constituiu indefectível elemento componente da atmosfera cultural de São Paulo na primeira metade do século XX. Pode-se até acrescentar que este neokantismo, que foi diluído em caldo eclético, teria direito talvez a reclamar por alguns antecedentes históricos, situados na passada centúria, referentes a um vago kantismo em que laborou superficialmente, entre outros, o padre ANTONIO FEIJó.

10. Cf. Giorgio Del Vecchio, A Justiça, tr., ed. Saraiva, São Paulo, 1960, pp. 71-75, especialmente a Nota 1.

11. CD, p. 542 . 
Este inesperado subjetivismo aparece também na coincidência do autor com algumas noções características de PETRAZICKI, já então em sentido mais psicológico e menos metafísico. ${ }^{12}$ "A norma fundamental da ordem ética não é, entretanto, um princípio a priori. Ela resulta de uma intuição do espírito, isto é, de uma impressão que o espírito tem de si próprio. 0 espírito jamais teria uma impressão de si próprio se não experimentasse sua existência." 13 A ordem ética "compõe-se de um imperativo categórico, que é a norma fundamental, imposta incondicionalmente por uma exigência intrínseca do espírito humano; e de imperativos hipotéticos ou condicionais, decorrentes dos juízos normativos." 14

Eis uma primeira conseqüência desse subjetivismo do professor GOFFREDo TELLES JÚNIOR, na ordem ontológica: "O eu é um prius absoluto. A consciência do não eu depende da consciência do eu. Eis por que o eu é o critério do ser." 15 Como conciliar este extremo subjetivismo - metafísico e psicológico (intuitivo, introspectivo) - com suas anteriores e posteriores profissões de fé na objetividade dos resultados e dos métodos da ciência experimental? A essa atitude em face da questão do ser sempre se deu o nome de idealismo.

Uma segunda conseqüência se tira das palavras mesmas do autor, claras e concisas, nessa parte final do seu livro, no que tange à ordem dos bens e dos valores: "o eu é o fundamento, o critério, o elemento de referência, para a medida de todos os valores." 16 Se o eu é o critério dos valores, tal conclusão se qualifica, no plano da ética e da axiologia, como relativismo subjetivista.

Terceira conseqüência, na esfera do agir, se extrai por si mesma desta esboçada teoria natural do direito, quando encadeamos alguns de seus textos: "os julgamentos do espírito acompanham, sem cessar, a ininterrupta ação humana." ${ }_{17}$ "O homem é artífice de cada momento consciente de sua existência." 18 A sociedade não é só natureza, "é também contrato, porque é da vontade humana viver em sociedade." ${ }^{19}$ E final-

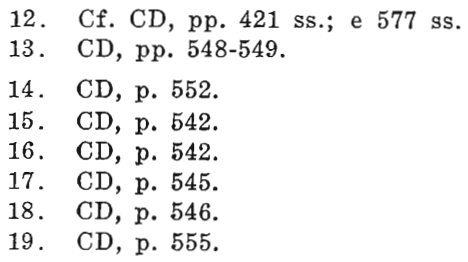


mente o autor se resume na terminologia delvecchiana: "O eu é a razão do dever-ser." Semelhantes conceitos é de rigor denominar, em seu conjunto lógico, voluntarismo.

Uma quarta conseqüência das posições do autor erige-se em tese expressa: "as ordens éticas, nas suas origens, são sempre individuais. Cada homem é seu primeiro legislador." 20 Mas como pode, então, a ordem ética individual mudar-se em ordem social, para se impor, "com seus mandamentos e preceitos de dever, a uma coletividade inteira?" A resposta, de lógica formal aparente, salta-nos de pronto diante, automática: "cada homem, legislador de si mesmo, se imporá deveres em função do bem comum." ${ }^{21}$ Assim, a ordem social (e a jurídica) não é senão a ordem ética individual ampliada, desde o momento em que o indivíduo ponha o bem comum na mira da sua razão prática, como alvo de sua vontade. É sempre, porém, a consciência isolada que, convergindo com a multidão das outras consciências singulares, vai com elas eleger uma representação mental ou idéia comum para, guindando-a, redoirada, à condição de bem, buscar realizá-la ou vivê-la. De modo que, no fundo, a adesão do indivíduo ao bem comum, ou à idéia coletiva a realizar, aparece, nessa perspectiva, como simples astúcia do homem que visa, na realidade, a alcançar seus próprios fins, executar seus projetos particulares. A comunhão é, portanto, apenas um meio para os indivíduos, que - eles sim se constituem como fins. ${ }^{22}$

Esta visão do mundo, é claro, se chama individualismo, a despeito do uso que se faça do significante bem comum, o qual remete a um significado antigo e a outro medieval, que se inserem, ao contrário, em estruturas destituídas de qualquer conotação individualista.

Ora, idealismo, relativismo subjetivo, voluntarismo e individualismo são concepções que, referidas ao direito, constituem um impossível adminículo ${ }^{23}$. Mas quem vem, de feito, submià objetividade científica, à razão dialética e à supremacia da comunhão, que definem a teoria do direito de ARISTótELES e a de S. TOMÁS DE AQUiNo. Este é, no entanto, chamado à colação, a folhas tantas, na intenção de emprestar ao nosso professor um impossível adminículo ${ }^{23}$. Mas quem vem, de feito, subministrar-lhe inexplícito, embora evidente reforço, é o seu colega,
20. CD, p. 565 .
21. CD, p. 567.
22. CD, p. 565 .
23. CD, cf. p. 564, entre outras. 
igualmente ilustre, professor Miguel REALE. Eis a prova, que me podem reclamar: "A norma não surge do facto e não surge do espírito; surge, isto sim, do espírito colocado diante do facto: do facto julgado pelo espírito; do espírito julgando o facto. A ordem ética repousa em três elementos entrosados: espirito, facto e norma" 24 .

Quando se recorda que, segundo o nosso autor, o eu é o fundamento do valor, "a razão do dever ser", e que este eu é espirito, torna-se evidente que $o$ bem e a sua medida, o valor, equivalem ao conceito e ao termo espírito. Assim, onde o professor GOFFREDo TELLES JÚNIOR escreve espírito, o professor REALE lê: valor. Nesta passagem, pelo menos, um e outro falam a mesma coisa: a moral e o direito se reduzem a fato, valor e norma. Mas esta fórmula, destinada a surpreendente irradiação, cabe melhor estudá-la, quem sabe? em ensaio dedicado ao professor MIGUEL REALE.

Prosseguindo no trilho de nossas considerações sobre a Criação da ordem humana (terceira parte do livro), cumpre observar que o autor nos oferece ${ }^{25}$ três notas comuns a todos os grupos sociais: "Verificamos que as duas primeiras são a idéia de um bem a realizar e a comunhão humana. A terceira é a seguinte: cada um desses grupos tem o seu governo" ${ }^{26}$.

A propósito do governo, "órgão do poder", o sr. GOFFREDO TELLES JÚNIOR continua a desenvolver bem articulada teoria social, estatal e jurídica, inspirada em HAURIOU ${ }^{1}$. A sua construção teórica deveria erguer-se, quando acabada, sobre esse tipo de idéias. (Verdade é que, no que toca a HAURIoU, a noção de idéia inclui, em sua extensão, o que o jurista francês qualifica, algo insolitamente, de "idéias inconscientes"). Procede a uma espécie de operação de estaqueamento, batendo insistentemente sobre a mesma idéia. "O poder se acha, portanto, na idéia a realizar e, por extensão, nas normas necessárias a essa realização" ${ }^{27}$. "O poder está na idéia, o governo está no chefe" ${ }^{28}$. "Mas, individualizado ou não, o governo só é legítimo se for, realmente, órgão do poder, isto é, se estiver a serviço da idéia para cuja realização o grupo se constituiu" ${ }^{29}$. E quando o governo se torna ilegítimo, a sua força passa a opor-se ao "poder das idéias"; mas este termina por prevalecer.

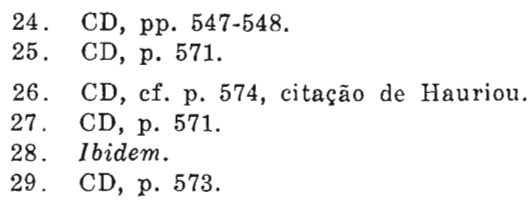


É lícito supor-se que a sociedade civil possa organizar-se naturalmente em estado, não em função de idéias, mas de necessidades. Na verdade, essa idéia de HAURIOU, mais ou menos clara e distinta, nã̃o deixa espaço às necessidades próprias da natureza das coisas, que é a estrela polar da teoria clássica do direito natural, tal como tem sido restaurada pela crítica histórico-filosófica nas últimas décadas ${ }^{30}$ Em nosso autor, como já em HAURIOU, idéia é muito menos um conceito lógico que uma representação mental coletiva, portadora de fins e de valores, configurando certa noção de bem comum.

Entende que, para conseguir tais objetivos sociais, é essencial que o governo declare as normas constitucionais para, em seguida, "garantir pela força o seu cumprimento" ${ }^{31}$. Observa muito justamente, no tocante à autoridade das leis, ou seja, à razão de sua obrigatoriedade: "A conviç̧ão de que o governo é legítimo gera a conviç̧ão generalizadora de que a norma, por ele selecionada, é necessária para os fins sociais e deve ser obedecida" ${ }^{32}$

Assim legitimado (outros diriam fundado, justificado) o governo (outros diriam estado, poder político), adquire este a condição geralmente consentida de atribuir a quem for lesado pela violação da norma, "a faculdade de exigir o seu cumprimento", com "o apoio da força organizada do governo" Isto porque, acrescenta, "o cumprimento dessa norma não interessa apenas aos lesados, mas a todos os componentes do grupo social" ${ }^{3}$.

Duas observações críticas desde logo cabem aqui a propósito da passagem supra resumida. Primeira, o autor não define a substância da idéia que cristalizaria os fins sociais, não determina concretamente os seus elementos componentes, como tampouco refere as formas e processos aptos à conscientização dessa idéia (que é fim, valor a realizar, programa etc.) pela maioria real da população. Quer dizer: a distorção casuística da vontade popular, a marginalização política das massas majoritárias, a manipulação da opinião das classes médias e proletárias pelos media, entre outras questões, não estão incluídas nas considerações e fórmulas gerais que o autor vai buscar

30. Cf. as obras de autores como M. Villey, A. Brimo, Graneris, H. Thieme, R. Marcic; e traduções de Aristóteles, como as de W D. Ross e GAUTHIER.

31. CD, p. 575.
32. Ibidem.
33. CD, p. 576. 
nos seus autores. Também não estão implicadas nas reflexões da sapiência tradicional ou nas frases sentenciosas e, por vezes, profundas, que enriquecem abundantemente, como tecido intersticial, o encadeamento formal do seu raciocinar. Este raciocínio avança com solenidade, alinhavando, de modo original, as idéias que vai sopesando e elegendo nos escritores de sua preferência.

Segunda observação. Não fica provado que o "cumprimento da norma", de acordo com a realidade cotidiana e a verdade concreta - interessa mesmo "a todos os componentes do grupo social". Nos processos de sua gênese e de sua efetivação, a norma - conforme o estado atual de nossas instituições - é, em geral, a expressão de uma vontade de classe, economicamente dominante e ideologicamente hegemônica. Dir-se-ia que era por aqui que convinha começar o pensamento orgânico da Criação do direito.

Só "o governo", portanto, tem poder ou, digamos assim, é poder para conferir à norma "a qualidade" de atribuir "a faculdade" de exigir o seu cumprimento. Em suma, ressalte-se: só "o governo" pode atribuir - por meio de norma - a faculdade de exigir o cumprimento das normas, garantindo-o pela força (na falta de seu cumprimento espontâneo ou voluntário - parece-me que se deveria acrescentar).

Por conseguinte, este atribuir, este tribuere é um privilégio do estado, ou melhor (para ser fiel à terminologia do nosso autor), do "governo". Por isso, só a norma promulgada pelo "governo" é jurídica. O "governo" é, portanto, a única fonte produtora de normas jurídicas; correspondentemente, é óbvio que as normas produzidas, isto é, promulgadas pelo "governo" são, em princípio, a única fonte ou forma de direito, enquanto precisamente são o produto da vontade criadora do "governo" Daí a definição de direito que nos dá o autor ${ }^{34}$, na qual direito e norma são conceitos equivalentes: "o direito define-se: norma que, promulgada pelo governo, atribui a quem seria lesado por sua violação, a faculdade de exigir o seu cumprimento". E ajunta: "a expressão norma atributiva é suficiente para definir o direito" 35.

Tomada isoladamente pelo menos, essa é uma definição que um kelseniano ou outro normativista qualquer subscreveria sem constrangimento. Resta-me perguntar agora que uso fará o leitor daquele implacável libelo crítico desfechado contra

34. CD, p. 576 .

35. CD, p. 576 . 
KELSEN na segunda parte deste livro ${ }^{36}$, onde apropriadamente a teoria pura é encaixada no capítulo do "Direito Metafísico". Mas a surpresa do leitor sobe de monta ao comparar a definição do direito acima com a assertiva imediata, na página seguinte: "E como o direito que acabo de definir, sendo o único direito verdadeiro, decorre da própria natureza das coisas, eu o qualifico de direito natural, em oposição aos falsos direitos, que só se manifestam nos decretos dos déspotas, e em contraste com os direitos imaginários e fictícios, que só existem na mente de alguns doutrinadores" ${ }^{37}$.

Contudo, manda a verdade que se situe aquela definição no conjunto deste livro e da obra do autor. Ele contém pressupostos, digressões e comentários que permitem estabelecer a coerência entre uma definição positivista do direito e a sua qualificação como direito natural. A chave ou a premissa ausente, que possibilita a conseqüência do entimema ${ }^{38}$, pode ser formulada do seguinte modo: Todo instrumento da idéia social é natural. Enunciada esta premissa, temos o silogismo:

Todo instrumento da idéia social é natural,

Todo direito positivo é instrumento da idéia social,

Todo direito positivo é natural.

A inclusão do direito positivo no direito natural é mediada pelo termo (médio) idéia social. Todavia, parece que alguma idéia social não é natural: a "solução final" para os judeus na Alemanha nazista, o suicídio coletivo da comunidade do Reverendo Jones, na Guiana, a prática do crime como fim numa cáfila de ladrões etc. Parece também que nem todo direito positivo, isto é, posto pelo "governo", é necessariamente instrumento ou meio de realização da idéia em função da qual os indivíduos se reúnem. Nem só os decretos despóticos ou o direito imaginário de certos teóricos ficcionistas são falsos direitos. Em sociedade de classes e antagonismos inconciliáveis, como a nossa, o governo se identifica com um pequeno grupo de pessoas, em regra, estamental (tecno-militar-burocrático), que é mandatário dos economicamente mais fortes e dominantes. Por isso, o direito é sempre apenas a expressão normativa e coactiva de uma minoria que impõe, pela astúcia, a mentira e a força (inclusive através do uso ideológico da ciência, artes, filosofia e religião) a sua idéia coletiva, mas minoritária, às grandes massas manipuladas (como um reba-

36. Cf. CD, supra pp. 209 ss.

37. CD, p. 577 .

38. O entimema articula-se na passagem da p. 576 à 577. 
nho) pelos aparelhos e técnicas que esse grupo controla e dirige a seus fins particulares. Como se pode pois julgar a idéia, ou melhor, o interesse de alguns como sendo a idéia, ou antes, a necessidade de todos ou, pelo menos, da maioria?

De resto, o grupo não se constitui para a realização da idéia ${ }^{39}$ Sustentar que os indivíduos se reúnem a fim de se constituírem em grupo político em função de uma idéia, organizando-se assim em poder político (para dar-se ao mesmo tempo um governo que, nesse mesmo ato, e tão somente nele, se legitima), é reelaborar a bela construção institucional de HAURIOU. Mas com HAURIOU ou com o professor GOFFREDO TELLES JÚNIOR, essa concepção sacrifica, de modo fundamental, nas aras do contrato social e do positivismo político-jurídico. Lá se vão os indivíduos solitários em busca de outros para, reunidos, celebrarem o famoso pacto social, que deixa para trás os direitos naturais a fim de instituir e constituir - sobre a vontade geral - o estado, que desde agora passa a fundar e criar todo o direito ${ }^{40}$.

À doutrina individualista do contrato não falta sequer, no livro em exame, o colorido romântico dos mitos ${ }^{41}$ : "A sociedade é natureza e é contrato". O homem é social estruturalmente, "mas se, por qualquer excepcional motivo, não precisar da sociedade para atingir seus fins, poderá viver voluntariamente fora dela, como sucedeu a JoÃo BAPTISTA e a ANTôNIO, o eremita" Omitindo embora RoBINSON CRUsot, o solitário de ficção predileto dos economistas clássicos, nem por isso deixa o sr. GOFFREDo TELLES JÚNIOR de ocupar tranqüilamente, nesse momento, o seu lugar entre os adeptos do liberalismo econômico e do individualismo político. Mas neste liberal-individualismo enxerta o autor aquela admiração que a burguesia nutriu sempre pelos valores feudais e monárquicos: "Todo governo legítimo há de ter, portanto, um caráter aristocrático; só uma cega ou interesseira demagogia sustentaria o contrário" ${ }^{42}$. Dir-se-ia que desponta aí o discreto "charme" da classe burguesa. Mas, não; o autor quer dizer que esse tipo de aristocracia forçosamente resulta do inevitável processo poli-

39. CD, p. 577.

40. Parece-me ter dito o bastante para demonstrar, ou seja, ilustrar aquela constante do autor referida no início deste estudo: o seu reconhecimento da ordem jurídica como realidade irredutivel, que ele vê em perspectiva iniludivelmente positivista, no sentido da escola da exegese.

41. CD, p. 555 .

42. CD, p. 589.

43. CD, pp. 588-589. 
tico de representação e delegação ${ }^{43}$ no governo, cujos membros devem possuir qualidades morais e técnicas especializadas e superiores às dos cidadãos comuns, seus mandantes teóricos, que só podem lucrar ao alhear-se dos ônus dos negócios públicos ${ }^{44}$.

Neste passo já me parece oportuno fazer algumas observações sobre as idéias que venho de expor acima. Antes, porém, julgo necessário firmar alguns princípios, por amor à verdade e pelo dever que decorre de minhas convicções filosóficas, onde se incluem necessariamente as políticas. Pois entendo que um pensamento filosófico que não se situa politicamente não responde à natureza mesma do homem, que só pode construir sua existência quando historializa as suas possibilidades, ao mesmo tempo em que lhe confere, nessa direção da prática e do cotidiano, toda a autenticidade que é capaz de sacar de si mesmo. $\mathrm{E}$ essa realização do próprio ser, que resulta do esforço sempre inacabado de unificar, re-unir a própria existência em seus modos autêntico e inautêntico, o homem só o consegue com o "tornar-se o que é", quer dizer, procurando e vivendo a sua vocação, transformando em dever o seu destino.

Antes de voltar ao trecho examinado, observemos que a Criação do direito - como já assinalamos no princípio constitui o registro resumido da primeira etapa da evolução intelectual do professor GOFFREDO TELLES JÚNIOR, enquanto as fases seguintes, até o presente momento, são documentadas pela Filosofia do direito e o Direito quântico. Pelo menos, essas obras foram a nossa escolha metódica para a análise do seu pensamento jurisfilosófico. Elas são suficientes para lhe determinar a unidade e descrever seus aspectos contraditórios, vale dizer, dramáticos. A unidade de uma vida (mesmo quando se lhe segue apenas a vertente intelectual) é a linha que une, com precaria harmonia, as contradições que a forram.

Quem - com interesse e simpatia - percorreu os trabalhos do sr. GOFFREDo TELLES JÚNIOR até hoje sente que, nesta derradeira parte de seu livro, vibra um irrecusável acento dramático, sobretudo quando a compara às etapas posteriores de sua biografia intelectual, que se exprimem naquelas duas obras que se lhe seguiram. Esta sensação se intensifica ainda quando se reconhece nesta evolução um caso particular da formação cultural do homem brasileiro, um exemplo, entre tantos outros, em que se reproduzem traços comuns e as mesmas invariantes da inteligência nacional. Aí está mais uma

44. CD, p. 589. 
razão para que a produção de um escritor e professor brasileiro, como este, seja estudada não só à luz dos critérios científicos consagrados, mas também a partir de um ponto de vista nacional, de perspectivas e valores próprios do seu povo, a que o vinculam indissoluvelmente a história, o trabalho e o futuro comum.

Esta Teoria natural do direito, exposta sob o título de A criação da ordem humana, ao mesmo tempo em que sintetiza as observações de leitura do autor, como ele decerto desejara, acabou por se tornar e permanecer a antecipação matinal de suas pesquisas e escritos ulteriores, como ele não poderia prever. De fato, ali se anuncia a coerência da obra e ali incubam já as contradições que o tempo, longe de reduzir, aprofundará.

Continuemos, pois.

Primeiramente, ao contrário do que admite o nosso professor, aludindo a JoÃo BATISTA e ao eremita ANTÔNIO, a vida solitária é, antes que exceção, uma simples ilusão de ótica, digamos assim. Na verdade, aqueles santos e outros que foram viver no deserto, ou se apartaram do convívio de seus semelhantes, levaram sempre consigo, entressachados no tecido do seu psiquismo as representações, os motivos, as tradições, os fins, as expectativas do seu meio social e da humanidade. Todos esses fenômenos, originários ou adquiridos, constituem a estrutura da personalidade, formam o homem existente, têm um conteúdo de interação e intersubjetividade, substância que é puramente social, tanto mais social quanto mais psicológica. Como os animais de que fala o texto, também o homem morre ou enlouquece no isolamento, quando este é real. Quem verdadeiramente se isola é porque já está vazio de toda a realidade humana, seja processo, energia, estrutura, seja substância, existência, ser-aí.. Corporalmente isolado, o ente humano continua a participar do ser social; noutras palavras, é ele mesmo enquanto é socialmente. Ser é ser no mundo com os outros; ou nestes termos: é ser o mundo e ser os outros. No mundo, nos outros e em mim há ser em devir. O mundo, os outros e eu juntos devimos em ser. O nós precede ontologicamente (e é o que importa) o $e u^{45}$.

45. Sobre este parágrafo, cf. Aloysio Ferraz Pereira, Estado e direito na perspectiva da libertação, Rev. dos Tribunais, 1980, onde, no mesmo sentido são estudados e citados Aristóteles, Rousseau, Heidegger, Levi-Strauss e Binswanger. Quantos mais se poderiam referir! Mas para quê? Basta observar a natureza... ou re-citar o mesmo professor Goffredo TELles Junior, CD, p. 555: "é da estrutura humana a inclinação para a vida social." 
Em segundo lugar, a representação política conduz ou tende a conduzir os representantes à falsa noção de sua superioridade em relação aos representados, assim reforçada pela distância que passa a separá-los e inveterada no hábito do exercício dos poderes em que foram investidos precisamente por seus mandantes. Eles sempre governaram em nome do povo, mas por conta daqueles a cujos interesses servem e dos quais também se beneficiam. A delegação política é sempre abdicação de poder e de direitos por parte do cidadão que os delega. $O$ povo não pode renunciar à democracia direta sem demitir-se de sua soberania. Supondo mesmo que esta forma de governo seja utópica e impossível, não resta ao povo (dele excluída a classe dominante) outro comportamento a adotar senão empenhar-se, sistemática e obstinadamente, em pressionar as camadas sociais no poder, para forçá-las a aceitar a participação do maior número nas decisões dos interesses da maioria que, em nosso tempo, é sempre constituída de trabalhadores assalariados.

No estado burguês como no estado operário, é necessário que haja - tal é a lição dos fatos e da história - "um controle permanente e extenso por parte do povo sobre os que exercem funções públicas; e a separação, entre os que exercem o poder e aqueles em cujo nome é exercido, será tão pequena quanto possível (...) As funções de Estado devem ser exercidas, em escala sempre crescente, pelas massas como um todo" ${ }^{46}$.

Enquanto os indivíduos, no seio das massas, se dedicarem somente ao exercício de sua profissão, satisfazendo sua vocação e necessidades materiais, ou ao cumprimento de deveres exclusivamente pessoais e familiares, e não dispuserem de tempo para assumir sua parcela de responsabilidade nas decisões políticas, eles serão traídos e oprimidos pelos poucos que governam em seu nome. Por isso é essencial e irrenunciável a luta pela redução das horas de trabalho, para permitir que as massas se instruam e se preparem; e a fim de que tenham tempo para assumir o seu papel decisório nas assembléias, porque estạ ainda não encontraram sucedâneo.

Em terceiro lugar, o professor GOFFREDo TELLES JÚNIOR, ao termo desse Esboço ${ }^{47}$, como quem coloca o fecho numa abóbada, ali encaixa o conceito de nação, que define: "sociedade cuja idéia a realizar é a de se constituir a mais alta

46. ERnest Mander, Teoria marxista do estado, ed. Antídoto, Lisboa, 1977 , p. 40 .

47 CD, p. 603. 
condição social (a condição incondicionada), para que as entidades, que ela encerra, melhor se aproximem de seus respectivos fins" ${ }^{48}$. Nação pois é o termo que significa a sociedade política mais abrangente e mais alta, de modo que todos os demais direitos objetivos dependem do direito positivo nacional ${ }^{49}$. Se a soberania é a faculdade de decidir, em última instância, sobre a atributividade das normas ${ }^{50}$, só a nação é soberana. Atributividade é noção que fez alguma carreira no Brasil, empregada também pelo professor MigUel REALE ${ }^{51}$, mas em sentido um pouco diferente, pois ele lhe acrescentou a qualidade de "bilateral". Ambos estes autores brasileiros retiram o essencial de sua noção de atributividade de idéias de PETRAZICKI, através principalmente de seus divulgadores em francês, G. GURVITCH e GEORGES CORNIL, que dele se ocuparam nos Archives de philosophie du droit et de sociologie juridique, respectivamente de 1931 (3-4) e 1934 (1-2). Fica subentendido, embora com economia das razões disso, que tais sentidos de atribuir nos levaram muito longe da acepção clássica, que se encontra em ARISTÓTELES, no direito romano e SÃO TOMÁS DE AQUINo.

Parece-nos, ainda, que o conceito de nação é menos próprio, na espécie, que o de sociedade civil ou, mesmo, política, pois há sociedades civis e estados que unificam, confederam (Suíça) e federalizam (URSS) nações muito diferentes entre si (guardada a definição que de nação nos deu RENAN e que é a usual, cf. o Novo Aurélio) Demais, o termo padece de pesada herança semântica, que data da aventura nazi-fascista, com larga voga oficial também no Brasil. No período do chamado Estado Novo a retórica ditatorial e a imprensa censurada davam ao termo uma enfática ressonância e o escreviam invariavelmente com inicial maiúscula, bem como o seu derivado "Nacionalidade"

A noção de atributividade, além disso, a mim se apresenta como inútil circunlóquio mental, uma complicação, a que sempre me pareceu preferível a noção intuitiva e direta de obrigatoriedade ou autoridade das normas. Claro está porém que o conceito de atributividade é mais analítico que o de obrigatoriedade, e independente do de coercibilidade. $E$ certo que há normas jurídicas que não são coercíveis, como as de caráter meramente doutrinal ou metodológico. Mas até estas possuem

48. CD, pp. 603-604.

49. CD, p. 604 .

50. Ibidem.

51. Miguel Reale, Filosofia do direito, São Paulo, 1969, 2.ำ v., pp. 601 ss. 
a compulsividade da lógica. Os fatos sociais - e o fato jurídico é fato social - são coercitivos, como ensina a sociologia. Mas esta noção de atributividade implica em que as normas jurídicas, por isso que são essencialmente violáveis, são atributivas, isto é, atribuem aos lesados pela sua violação a faculdade de fazê-las cumprir ${ }^{52}$. Mas, sem a coação efetiva ou potencial, de que vale essa teórica atributividade? ' $\mathrm{E}$ a norma ética, fundada sempre no comportamento social e na consciência de nossa nulidade, não tem ela também atributividade teórica ou virtual e até prática? pois não se reconhece sempre ao moralmente, quer dizer, socialmente lesado a faculdade de fazer cumprir a norma? Ou será que ao lesado moralmente só se lhe deixam os olhos para chorar, reduzido, sem ação e sem apelo, à humilhação e ao ressentimento? Por aí toda ética seria ética do ressentimento. Em contrapartida, que valor têm faculdades e direitos subjetivos de ação que a Constituição e as outras normas atribuem aos indivíduos e às populações miseráveis, iletradas, marginalizadas? Seria infinito prosseguir

Reticenciemos, pois. Vamos ao ponto final nestes comentários sobre a Criação do direito, em cujas páginas conclusivas ressalta a seguinte distinção, ${ }^{53}$ ao mesmo tempo elítica e sutil, entre moral e direito: "O direito cuida do que o dever ser é, ao passo que a moral cuida do que o dever ser deve ser; acham-se, pois, o direito e a moral em planos diferentes: o direito, num plano natural, e a moral, num plano metanatural ou sobrenatural". E dessa distinção tira primeiro o autor uma conseqüência epistemológica: "Eis por que a teoria que acaba de ser exposta se denomina Teoria Natural do Direito". Em seguida, extrai uma segunda conseqüência, que se poderia dizer axio-teológica: "Ou a moral indica o bem supremo do homem, ou ela não tem razão de ser. Ora, a descoberta do bem supremo do homem implica problema que a razão natural não resolve. Os homens acreditarão em Deus, como Primeira Causa e último fim de toda a Criação, ou negarão Deus como uma fantasia desnecessária". ${ }^{54}$

Sobre as afirmações acima eis afinal algumas observações igualmente concisas. $\mathrm{O}$ autor, ao mesmo tempo em que os distingue, identifica, ou, se se quiser, identifica o direito e a moral na noção de dever ser. Distingue-os, porém, baixando o direito ao plano natural, enquanto guinda a moral ao plano sobrenatural. Todavia, se assim o tivermos situado entre os fatos
52. CD, p. 582 .
53. CD, p. 605 .
54. CD, pp. 605-606. 
naturais, o fenômeno jurídico passa a ser objeto de ciência natural, e é abrangido pela ontologia, caso em que o direito não mais deve ser, mas é. Só assim se justificaria (seria inteligível) plenamente uma teoria do direito que reclama o qualificativo de natural.

Quanto à moral, o professor GOFFREDo TELLES JÚNIOR conserva, a seu respeito, concepção religiosa e cristã ou, melhor dizendo, escolástica, no sentido em que nela o homem é visto ou posto, essencialmente, em sua relação com Deus; e só secundariamente (sobretudo na justiça) aparece relacionado com seus consócios e com a sociedade. Não se trata pois da idéia antiga, de um ARISTóteles, onde a moral é sempre social, implicando necessariamente os outros, mesmo nas demais virtudes que não a justiça. Também não é a atual compreensão, de um MARX ou de certos existencialistas, para quem a personalidade ética individual é apenas um perfil linear, um desenho delével na massa englobante do mundo e da coexistência com outros entes e homens.

Como "a razão natural" (na expressão de nosso professor) não tem forças para descobrir o bem supremo do homem, só lhe sobra, para essa descoberta, a opção da fé, só lhe resta "acreditar em Deus, como Primeira Causa e último fim de toda a Criação". Eis aí de novo idéias e termos recebidos da escolástica e do cristianismo. Curiosa teoria essa que, ao longo da sua exposição, quis ser científica, em sentido experimental, e que, ao seu termo, se põe na dependência de Deus, considerado não como princípio racional, mas como objeto da fé cristã. $\mathrm{O}$ amor da razão acaba por subordinar-se à razão do amor. Decerto o corpo do direito positivo precisava mesmo - para ficar no domínio da verdade, mas além da lógica das normas - daquele "suplemento de alma" que exigia BERGson. E o nosso mestre conclui : "o direito, como o amor, tem a sua fonte originária no coração dos homens" ${ }^{55}$ E interessante notar ainda que, ao fim, o autor data o seu livro do "dia da Ascensão do Senhor" Retenha-se este marco na memória, para que se possa mais tarde bem medir toda a distância que há de separá-lo do Direito quântico.

\section{Da natureza do direito (FD) ao direito da natureza (DQ)}

Esta segunda parte do presente ensaio não será simétrica à primeira (dedicada à Criação do direito), em termos de espa-

55. CD, p. 606. 
ço físico. Guardará, porém, com aquela uma justa proporção, pois é a essa primeira obra que atribuímos, na perspectiva deste estudo maior densidade relativa no conjunto dos trabalhos do autor. Se este ensaio "termina em cauda de peixe" é porque entendemos que as características essenciais do pensamento do professor GOFFREDo TELLES JÚNIOR encontram-se delineadas na obra que vimos de estudar. Ali estão pontos de partida de sua reflexão, muitas posições que se destinavam a permanecer e fontes decisivas de seu trabalho intelectual. Ali também se estabelecem, com nitidez, certas afirmações que, parecendo embora bem alicerçadas em raciocínios e convicções, foram mais tarde negadas por sua própria evolução. Tais contradições assinalam o curso de seu amadurecimento, acusam tentativas de renovação e testemunham a busca de maior autenticidade por quem assume, com coragem, o risco de contradizer-se. Deve-se observar, mais uma vez, que contradições dessa natureza são apenas abstratas e aparentes, pois desaparecem na lógica da existência. Basta, muita vez, o recuo de algumas décadas e as fases que se contrariam já se compatibilizam por si mesmas, nesse modo de encadeamento que imita, no real exterior, o movimento dialético do pensar. Outras vezes, os aspectos colidentes da conduta e do discurso individuais adquirem ou recuperam sua coerência quando - à distância temporal - vão aparecer ocupando o lugar que lhes é próprio na composição do quadro coletivo nacional, dentro de cada época, em harmonia com a formação histórica do respectivo povo. Na verdade, por mais rica que seja uma personalidade, só alcança a plenitude na realização de sua existência social. E o seu sentido só é determinável a posteriori, em retrospecto, ao emanar de todos os seus atos, considerados na trama das relações sociais, na conformidade do destino comum (cp. últimas palavras do Édipo-rei de Sófocles).

De modo correlato, ao analisar um itinerário de escritor ou a produção de um professor, como agora fazemos, sentimos que a nossa tarefa só verá completar-se o seu sentido e adquirir utilidade a partir do momento em que, inserindo-a no conjunto do grupo ou grupos sociais a que pertence, conseguirmos determinar as relações que essa obra mantém com o seu meio e fixar em que medida tira sua origem e se mostra expressão desta sociedade. Do mesmo passo é mister avaliar, quando possível, a contribuição social que ela proporciona.

Vamos pois resumir as observações que nos suscitam as outras duas obras que escolhemos como as mais características. 


\section{Filosofia do direito}

O título acima refere-se ao manual ${ }^{56}$ bastante desenvolvido (542 páginas) em que o professor GOFFREDO TELLES JÚNIOR reuniu matérias que correspondem, de modo geral, ao programa que tem exposto em seu curso de Introdução à ciência do direito na Faculdade de Direito da Universidade de São Paulo. $O$ primeiro tomo promete, em seu título, cuidar exclusivamente do "conhecimento humano". Contudo, além da questão gnoseológica propriamente, trata de temas clássicos de filosofia, lógica, ontologia (metafísica tradicional e bergsoniana), axiologia, ética e outros sobre os dois eus e a concepção do mundo. Entretanto, a maioria dos assuntos é versada, predominantemente, sob o ângulo da teoria do conhecimento, por exemplo: a intuição do eu, intuição do ser, intuição do honesto e do justo etc. (lugares onde é largamente acolhido - é claro - o intuicionismo bergsoniano). A matéria deste primeiro tomo pode ser caracterizado como provinda, prevalecentemente, de duas fontes: neotomismo e HENRI BERGSON.

O segundo tomo volta inicialmente a questões metafísicas (Os princípios e as causas), aflora salteadamente problemas vários: cosmológicos ( $O$ universo), epistemológicos ( $A$ divisão da ciência), sociológicos ( $A$ sociedade humana) e políticos ( $A$ sociedade politica) para afinal focalizar, privilegiadamente, grandes tópicos da filosofia moral ( $O$ mundo ético), vistos sobretudo à luz da psicologia, e, com maior amplitude, temas fundamentais e convencionais da filosofia jurídica ( $A$ ordem e a lei, As normas, Pluralismo das ordenações jurídicas e unidade do sistema juridico, Fundamento natural da ordem juridica, $O$ direito subjetivo, $A$ justiça e $A$ definição do direito).

Note-se, de passagem, que o estilo, nesta obra, evoluiu no sentido da sobriedade. As frases são mais curtas, buscam a expressão definitiva, a clareza, a simplicidade. Em compensação, não há engano em dizer-se que, apesar dessa concisão - e simultaneamente - o discurso adquire acentuação autoritária, como a que é própria da tradição dos compêndios da filosofia escolástica e dos textos de lei. É um tipo de comunicação que, em certa medida, barra a reação reflexiva do leitor e ouvinte, limita observações ou objeções espontâneas; de fato, porém, não faz senão adiar dúvidas e contestações, que terminam por erguer-se mais tarde. Esse tom dogmático exclui, por igual, em cada questão, aquela abertura dialética em que as

56. Aqui referido pela sigla FD. Filosofio do direito, 2 vs., ed. M. Limonad, São Paulo, s. data. 
principais soluções propostas são colocadas ou, por assim dizer, justapostas, para serem, a seguir, discutidas uma a uma. Este é, como se sabe, o método dialético que nos vem de SóCrates e Platão, que ARISTóteles torna menos ágil e dramático, porém mais demonstrativo, e que alcança, com ToMÁs DE AQUINo, aquela estrutura a um tempo sólida e flexível, que dá força e beleza à Suma Teológica. Mas não, não é esse o método desta Filosofia do Direito, elaborada para um curso de Introdução à ciência do direito. Esta destinação a um público de alunos do primeiro ano, naturalmente mais receptivos que contestadores, deve ter contribuído para o tom geral de exposição dogmática. Concomitantemente, o autor reduz ao mínimo referências aos conceitos que confirmam ou se opõem aos seus, abolindo as notas e aparelho crítico, limitando a bibliografia a algumas obras de sua preferência, acessíveis aparentemente ao nível de primeiranistas. No plano da filosofia geral, BERGSON é ainda, entre os contemporâneos, o mais citado, fornecendo materiais de fundação; enquanto o neotomismo (LEÃo XIII, MARITAIN, VAN ACKER, JOLIVET etc.) contribui também largamente para o desenvolvimento do curso.

No tocante à filosofia do direito, o autor é aqui influenciado pelas projeções das tendências mencionadas acima no campo da teoria jurídica. Alimenta-se, por outro lado, do idealismo à maneira de DEL VECCHIO e, em menor proporção, do idealismo do sr. Miguel REALE. Com este compartilha ainda a mesma postura conservadora diante da ordem jurídica (enquanto fato consumado) e a mesma atitude reverencial diante da legalidade positiva e formal, resultante das correntes tecno-jurídicas, que correspondem à ideologia liberal e contra-revolucionária. Esta segunda ideologia parece coincidir, ao nível da política, com as idéias de autores nacionais citados em sua pequena lista ${ }^{57}$ : OLIVEIRA VIANNA e prof. J. P. GALVÃo DE SOUZA.

Como já o fizera, mas de modo crítico, na Criação do direito, o professor GOFFREDo TELLES JÚNIOR continua a manipular, com inegável liberdade, as idéias de seus autores preferidos, procurando abrir, à custa deles, o seu próprio caminho. De modo tal que, se na primeira obra a qualidade mais saliente parece ser a coragem da crítica, nesta a virtude dominante é talvez aquela eciana "coragem de afirmar". Todavia, se nos é lícito opinar, diremos que este livro atinge o seu ponto alto ao baixar da metafísica escolástico-idealista, própria do neotomis- 
mo de Louvain (professor VAN ACKER, J. MARECHAL, etc.) ao intuicionismo de BERGSON. "Ante o fracasso das Metafísicas conceptuais, ante a esterilidade das dialéticas cerebrinas, 0 caminho único que se abre para o pensador é o que, afastado das paragens ideais em que a filosofia moirejou debalde durante tantos séculos, segue pelo terreno firme das percepções empíricas. Não se trata, evidentemente, de renunciar às faculdades de concepção e de raciocínio. 0 que se quer é que o concebido seja, por assim dizer, uma decorrência do percebido, a fim de que o conhecimento tenha consistência real". ${ }^{58}$ A partir desta opção pelo concreto, e sem largar o conceito de intuição (poder-se-ia dizer intelecção) ${ }^{59}$ peculiar à filosofia antiga e ao idealismo moderno, o professor GOFFREDO TELLES JÚNIOR adota, com entusiasmo, a intuição de BERGSON, integrando-a numa estrutura do fenômeno do conhecer, que não deixa de ser original sua ${ }^{60}$.

Chega ele assim ao modo de conhecimento intuitivo, distinto do conhecimento intelectual material. Dividindo a intuição em sensivel e intelectual, define a segunda ${ }^{61}$ como "apreensão mental de objeto imaterial (...) que se impõe à inteligência, independente de abstração e de raciocínio". Esta intuição intelectual denomina-a, coerentemente, de inteligência espiritual, que entende ser a via de acesso ao eu, como ente espiritual, e ao ser enquanto ser, bem como (através da simpatia) ao interior dos objetos ${ }^{62}$, em seu movimento e devir.

Mediante este modo intuitivo e espiritual da inteligência efetiva-se uma forma de conhecimento absoluto, descrito como "experiência", em que se verifica "assombrosa revelação", a descoberta do meu Eu Real, "que é espírito, e espírito somente!" ${ }^{3} \mathrm{E}$ mais: "Sendo só espírito, meu eu é indestrutível. Sendo indestrutível, é imortal! Sendo imortal, é invencível e eterno! Haverá descoberta mais importante do que esta?" 64

Entretanto, de todo o brilhante esforço desenvolvido no decorrer do primeiro tomo e em mais de dois terços do segundo, para entender e expor as questões preferenciais da filosofia tradicional e algumas idéias centrais da contemporânea, e para resumir matérias sem dúvida fundamentais de sociologia e

58. FD, p. 117.

59. O. Hamellin, Le Système d'Aristote, Paris, 1931, pp. 153 ss.

60. FD, p. 129, onde se tncontram claramente articulações dessa integração.

61. FD, p. 114.

62. FD, p. 121.

63. FD, p. 147.

64. Ibidem. 
política, pouco se colhe que seja diretamente aplicável às noções de filosofia jurídica, contidas na parte final da obra. Na verdade, conta este tomo, em seu texto propriamente dito, 527 páginas, das quais, a rigor, apenas 70 se ocupam de teoria geral e filosofia do direito. Este fato, porém, em nada diminui o valor da longa parte filosófico-sociológica e do relativamente breve espaço jurisfilosófico, considerados intrinsecamente, sem entrar no julgamento de sua adequação didática a um curso de Introdução à ciência do direito. Quanto a nós, temos a convicção de que os alunos só puderam ganhar com o plano da obra, e os que a leram, e atentamente estudaram, terão tirado o maior proveito tanto daquela vigorosa introdução à filosofia, quanto desta última parte, onde o nosso professor plantou, de modo categórico, o que lhe pareceu ser os pilares do direito.

\section{O direito quântico}

A tendência do professor GOFFREDo TELLES JÚNIOR a pesquisar no terreno das informações de ciência experimental, por nós caracterizada, no princípio deste estudo, como uma das constantes de sua atividade intelectual, termina por encontrar em seu livro $O$ direito quântico ${ }^{65}$ a sua expressão mais desenvolvida. Na Criação do direito abre-se o leque de suas várias possibilidades dominantes. Na Filosofia do direito desdobra-se afirmativamente a inclinação especulativa, que inflete, com fervor, na direção do intuicionismo. Já $O$ direito quântico registra a reflexão de leituras de física e biologia. É fácil perceber que após a publicação da Filosofia do direito, que condensa longos anos de ensino no curso de graduação de Introdução, estava o professor ansioso por acertar contas com aquelas ciências, cujos avanços e resultados procurou conhecer. Parece até mais preocupado em ampliar conhecimentos nessas ciências, e outras afins, do que efetivamente procurar - como prometia o subtítulo do livro - o fundamento da ordem jurídica.

Os leitores sensíveis mais ao apelo filosófico do que aos motivos científicos não deixarão de lamentar tenha o mestre deixado o rico veio do intuicionismo e da filosofia, que vinha explorando com êxito, a fim de minerar, nas aquisições da ciência, fatos e idéias com que ensaia ainda mais outra funda-

65. Aqui também indicado apenas com as iniciois DQ. O Direito Quântico, Ensaio sobre o fundamento da ordem jurídica, $5 .^{2}$ edição, revista e aumentada, São Paulo, 1980. 
ção do direito. Com efeito, na leitura de BERGSoN ele se preparara, e com paixão, a receber as soluções psicológicas ou, mais precisamente, a utilizar a saída intuicionista de PETRAZICKI, que suscitou o seu esquema de atributividade e direito subjetivo (com as noções de permissão, autorizamento etc.). Mas não há dúvida que é um direito seu - talvez o melhor - o de tentar novas veredas, satisfazendo, como notamos, um de seus pendores naturais. Não sei se todos os que o leram, o aprovaram; mas desconfio que preparar e escrever este livro lhe foi certamente enriquecedor e divertido. Afinal, entre outros, o princípio do prazer é um amável guia.

A nota preliminar dá-nos o seguinte resumo do espírito geral da obra: "A Teoria Quântica do Direito, o Quantismo Jurídico, é a tese de que o Direito se insere na harmonia do Universo e, ao mesmo tempo, dela emerge, como requintada elaboração do mais evoluído dos seres." "66 Na quinta edição, publicada cerca de nove anos após a primeira, o autor acrescentou à mesma nota: "O Direito Quântico é o Direito Natural - não o direito natural doutrinário ou ideal, mas o Direito Natural da natureza, que é o Direito que flui das realidades bióticas e genéticas dos agrupamentos humanos; o Direito que simplesmente exprime o "sentimento" e a verdadeira índole das coletividades em que ele vigora." 67

Observe-se desde logo que a quinta edição alterou substancialmente o texto anterior, isto é, o conteúdo único das precedentes edições. Seria, sem dúvida, interessante comparar essa primeira versão com a segunda, estabelecer as diferenças e determinar-lhes as causas. Limitar-nos-emos, porém, a cotejar a divisão da matéria num e noutro texto e a focalizar criticamente, em seguida, algumas articulações e aspectos decisivos.

$\mathrm{Na}$ versão das quatro primeiras edições a matéria acha-se assim distribuída:

"Nota preliminar

Cap. I - Visão do mundo

II - A liberdade

III - 0 sistema de referência

IV - O comportamento ético

$\mathrm{V}$ - A natureza das leis

VI - O direito quântico

66. DQ, p. 9 da $1 .^{\text {a }}$ ed. ou 14 da $5 .^{a}$

67. DQ, p. 14 da $5{ }^{a}$ edição. 
Breve Bibliografia"

A divisão principal na quinta edição é a seguinte:

"Nota preliminar

Cap. I I Visão do mundo

II - A liberdade

III - A unidade do mundo e a natureza das leis

IV - O sistema de referência

$\mathrm{V}$ - Juízos, valores e ordem ética. Mundo da cultura

VI - Biologia jurídica

VII - A norma jurídica

VIII - O direito subjetivo

IX - O direito quântico

\section{Breve Bibliografia"}

Tomemos em consideração doravante a quinta edição.

O capítulo I dá-nos, com efeito, uma visão do mundo, ou seja, simplificada representação mental da matéria e da vida, esboçada sobre a tela da imaginação com as tintas da divulgação científica e a espátula da lógica formal. Se o leitor jurista conseguir absorver as relativamente poucas expressões técnicas e acompanhar com perseverança o autor nessa linguagem nada familiar, acabará por admirar a coerência da exposição, no que o ajudarão, certamente, o colorido poético de tantas descrições, um freqüente tom de suspense e mistério e aquele pendor a teatralizar a natureza, personificando as coisas, pondo em cena ora personagens infinitamente grandes, ora infinitamente pequenas. Vejamos alguns exemplos, que ilustram esses aspectos que vimos de apontar.

"Há vinte ou trinta bilhões de anos, uma gigantesca nuvem começou a invadir os céus. Sua temperatura ascendia a milhões de graus" 68. "Vênus, a misteriosa - Vésper, Estrela da Tarde, Estrela do Pastor; Lúcifer, Estrela da Manhã,.Estrela d'Alva, Estrela do Norte, Estrela dos Navegantes; Deusa do Amor - Vênus se esconde por detrás de seus véus luminosos" 69 .

68. DQ, p. 15 .

69. DQ, p. 46 . 
"Surpresas extraordinárias estavam reservadas, para o homem, no âmago dos tijolos do mundo." 70 "Espantosa revelação esta! Mas eis que revelação análoga se fez relativamente a outras micropartículas. Os electrons, por exemplo, logo demonstraram ser energia, além de ser corpúsculos." 71 "Poder-se-ia perguntar: Que cousa é a fundamental: o corpo ou o campo?" 72

"Os átomos têm sido considerados os sistemas planetários do Microcosmos. Há, realmente, alguma semelhança entre um átomo e um sistema planetário. O núcleo faria papel de estrela, e os electrons, de planetas." "73 "Assim, nas profundezas da substância, uma misteriosa forma de liberdade parece patentear-se no indeterminismo operacional dos corpúsculos quânticos." 74 "Este é um fato realmente notável. O que neles mais surpreende é que cada electron parece manifestar suas propriedades como se tivesse vontade própria, como se fosse livre." 75

O leitor jurista que percorrer o livro será decerto grato ao autor de lhe ter resumido, de modo acessível e agradável, algumas das principais teorias da física e da biologia. Mas não deixará de notar que essa explicação ou visão do mundo, além de ocupar as 188 páginas do capítulo I (sobre as 433 do livro), estende-se pelo II, quando o autor entra, pela primeira vez, a falar em liberdade humana, à página 226. Mais da metade da obra, portanto, é exclusivamente dedicada a estabelecer os fatos físicos e biológicos que deverão servir de fundamento à ordem jurídica. Mas estou certo de que o leitor jurista nada tem a perder em seguir o professor GOFFREDO TELLES JÚNIOR empós do direito quântico; ao contrário, só tem a ganhar em demorar-se nesse terreno de ciência natural, que ainda aflora aqui e ali até o fim do livro. De fato, não prometera tratado de direito, mas exploração do seu fundamento.

Assim, cumpre ele a tarefa que se propusera, fundando os valores éticos e o direito na realidade e conhecimento científico do mundo e da vida. "E incontestável, portanto, que as ciências do Mundo da Natureza, de certa maneira, também são ciências do valor e que a denominação "Ciências do Valor" é imprópria para distingüir as chamadas Ciências Éticas, das Ciências Físicas." 76

$$
\begin{array}{ll}
70 . & \text { DQ, p. } 59 . \\
71 . & \text { Ibidem. } \\
72 . & \text { DQ, p. } 99 . \\
73 . & \text { DQ, p. } 102 . \\
74 . & \text { DQ, p. } 97 . \\
75 . & \text { DQ, p. } 95 . \\
76 . & \text { DQ, p. } 309 .
\end{array}
$$


Para o nosso autor, neste livro, a ciência natural é suficiente para explicar o surgimento da consciência e provar a existência da liberdade humana. 0 pensamento é condição da ordem e a lei é sua fórmula. ${ }^{77} \mathrm{O}$ regime democrático é a realização política da ordem natural, prefigurada no organismo humano, pois o "homem possui, em suas próprias células, os padrões da Democracia". ${ }^{78}$

Nas páginas em que trata especificamente dos temas jurídicos (norma e direito subjetivo) o professor reitera as teses expostas nos escritos e cursos anteriores, mas já agora sob a luz que sobre elas se projeta a partir da concepção científica e - porque não dizê-lo? - cientificista, que irradia dos pressupostos laboriosamente lançados nos capítulos iniciais e centrais da obra. Finalmente, algumas questões filosófico-jurídicas fundamentais ou de atualidade lhe merecem particular atenção: os direitos do homem, a fonte doadora de sentido e a experiência jurídica e, "last but not least", o direito natural.

Se o quantum é porção e unidade de energia irradiada ${ }^{79}$, "o direito legítimo é quântico porque delimita, quantifica" a energia humana, "segundo o sistema ético de referência que espelha disposições genéticas da coletividade." 80 "Em conformidade com o Direito Quântico, dentro da sociedade, um quantum de movimentação é exigível legitimamente." ${ }^{81}$ E o momento de recordar que a obra que ora examinamos começa por dizer ${ }^{82}$ : "O Direito Quântico é o Direito Natural" . . E eis que o tópico final repete agora conclusivamente: "O Direito Natural é Direito Quântico porque é o Direito reclamado pelas estruturas dos elementos quânticos, nas células dos componentes de uma população" 83 Entre uma e outra frase, a mesma frase, o professor GOFFREDo TELLES JÚNIOR esforçou-se por demonstrar, ${ }^{84}$ com recurso a dados científicos e emprego de raciocínio construtivo, que o direito tem sua base nos fenô-

77 DQ, pp. 261-263.

78. DQ, p. 339 .

79. DQ, p. 107.

80. DQ, p. 427.

81. Ibidem.

82. DQ, 5. ${ }^{\text {a }}$ edição, p. 14, Nota preliminar.

83. DQ, p. 426.

84. A concepção de direito natural do autor reduz-se, bem examinada, à modalidade determinista, apesar de não limitá-lo a leis eternas e imutáveis. A concepção atual do direito natural, nascida da rigorosa crítica histórica, e fundada em Aristóteles, rejeita todo determinismo, inclusive o de pretensōes científicas. 
menos da ordem natural. Entretanto, não pôde fazê-lo sem perder pelo caminho alguma coisa do que antes nos parecera inerente ao mais profundo do seu pensamento, porventura do seu sentimento. Por isso, é com certa consternação que alguns hão de ler ${ }^{85}$ neste Direito quântico: "Os fundadores das religiões, quando diziam receber mandamentos do Ente Supremo, nada mais fizeram, certamente, do que revestir, com os véus de uma piedosa fantasia, as mensagens íntimas de seu patrimônio genético." "As religiões são concepções primitivistas da realidade." 86 "Deus e as demais divindades sempre foram feitos à imagem do homem." ${ }^{87}$ Evidentemente, sem qualquer intenção malévola, é lícito medir daqui a distância que separa o autor das derradeiras páginas da Criação do direito e das inequívocas declarações de certeza espiritualista contidas nesse livro já longínquo, como também na Filosofia do direito. Alguns lastros, até então necessários ao equilíbrio do seu pensamento filosófico, foram descartados ou substituídos pela prestigiosa carga de electrons e proteínas. Mas a maior parte dos elementos e fontes de seu pensamento permanecem e são integrados unitariamente: por exemplo, o vocabulário e doutrinas neotomistas (JOLIVET, VAN ACKER, o padre MARECHAL), o evolucionismo intuitivo de BERGSON, a teoria liberal e conservadora do direito subjetivo, uma concepção muito positivista da norma jurídica etc. É de observar-se ainda a oportuna incorporação de várias citações de clássicos do marxismo, em abono de seus desenvolvimentos evolucionistas: MARX, ENGELS e LENIN, lado a lado, coincidentemente com SÃo ToMÁs e ARISTóteles. ${ }^{88}$ Sugestão talvez da leitura dos físicos e biólogos soviéticos citados na bibliografia. No essencial, não há muito que opor à aproximação desses autores, só em aparência incompatíveis, e entre os quais, ao contrário, apresso-me em reconhecer a existência de concordâncias decisivas e fundamentadas, que uma honesta comparação crítica autorizaria sem muito esforço.

$$
\text { * } * *
$$

Deixarei ao "leitor benévolo" as conclusões gerais sobre o pensamento estudado aqui. Quanto a mim, dada a abusiva extensão deste ensaio, reservo-me para publicá-las em outra ocasião.

85. DQ, p. 333 .

86. DQ, p. 332 .

87. DQ, p. 333.

88. DQ, pp. 86-93. 